\title{
A Look At The Attitudes Some Korean University Students Have Towards Different Accents In English
}

Alice Julianna Yoo, Hankuk University of Foreign Studies, South Korea

\begin{abstract}
Casual observation usually shows a tendency for most Korean EFL students to prefer the pronunciation of teachers from English speaking nations such as Canada and the United States. However, sometimes their preferences and the reasons for their preferences, may not always reflect reality. This paper examines the results of a survey done on 92 EFL university students in South Korea, where they had to identify an accent and answer questions on how positive or negative their attitudes towards the accents were. This paper also examines some implications of the survey.
\end{abstract}

Keywords: Krachu's Concentric Circle Model; Inner Circle; Outer Circle; Expanding Circle

\section{INTRODUCTION}

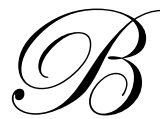

ecause of globalization and the widespread use of information technology, English has become a language of growing interest in many countries around the world, and as a result, many East Asian nations such as South Korea have undergone some dramatic changes in the area of English education (Butler, 2007; Kwon, 2000). However, with the spread of English around the world, "it is clear the English now has more non-native speakers than native ones" (Weeks, 1996) which I believe brings up the issue of preferences for particular accents by learners of English. This paper will examine the results of a survey administered to a group of Korean university students regarding their attitudes to accents used by English speakers from different countries. The author will discuss the implications of the findings for teaching English in the Korean context.

\section{LITERATURE REVIEW}

\section{Krachu's Concentric Circle Model}

Krachu brought attention to the proliferation of English through his three concentric circle model, by categorizing the different "World Englishes" as he coined the term, within the Inner Circle, the Outer Circle, and the Expanding Circle of his model (Rajadurai, 2005). The idea of Krachu's concept was to replace the traditional native-non-native labels that may have influenced our perceptions of and perhaps contributed to the belief in the superiority of certain groups, such as native speakers, over others in English. In fact, many may agree that consistent use of particular labels for a group can affect people's perceptions of members in that group and therefore distort 'reality' (Holmes, 2008).

Krachu's Inner Circle includes countries like Canada, the USA, the UK, Australia, and New Zealand, where English is the dominant language and the traditional mother tongue. The Outer Circle includes countries such as the Philippines, India, Kenya and others, many of which were former colonies of the UK or the USA. Because many of the countries in the Outer Circle have a colonial history with the English language, the function of English is primarily institutionalized or secondary to other languages that may exist in the cultures (Rajadurai, 2005). The Expanding Circle holds the greatest interest to me since South Korea, my working context, falls under this category, as does other East Asian nations like China and Japan, where English is generally used in very specific contexts, or as a foreign language for communication in international interactions (Rajadurai, 2005). 
Krachu further described the Englishes within his Three Circle Model as norm-providing, normdeveloping, and norm-dependent (Rajadurai, 2005). The Inner Circle can be seen as norm-providing, from which Expanding Circle countries, such as norm-dependent South Korea, get their English language model. Outer Circle countries can be seen as norm-developing, although because English generally tends to be institutionalized as described previously, and functions as an additional language rather than the dominant, countries in the Outer Circle may be seen as less favorable models for English.

\section{The Korean Context}

The early 1990's saw some dramatic changes in the way English was taught in South Korean schools (Kwon, 2000). Perhaps the biggest change was the introduction of English into the school curriculum as a regular subject and the Ministry of Education's 120 hour in-service training program for the Korean teachers who taught English. The majority of the program focused on developing the teachers' communicative ability with nativespeaking teachers (Kwon, 2000). Although, the introduction of English was generally positively received by teachers, parents, and students, another major impact was the huge influx of native-speaking teachers mainly from Krachu's Inner Circle countries. This influx of native-speaking English teachers had many Korean English teachers and learners realize the growing importance of communicative competence (Kwon, 2000). Traditionally, the teaching of English in many East Asian countries has focused more on grammar, reading, and writing, rather than speaking, which has naturally drawn some criticism (Butler, 2005). As a result, I believe more effort is being made in trying to improve the oral communicative ability of learners. However, the focus on improving the speaking ability of learners has also brought up questions of whether non-native speakers can be affective teachers and what kinds of attitudes the learners may have towards the speaking ability of their teachers (Butler, 2005).

\section{METHOD}

A survey was given to 92 of my students from the university where I teach Practical English. All students are non majors of English and their English abilities vary in range from completely beginner level to advanced. The questionnaire that I used was written in English and also translated into Korean with the intention that students could fully understand the questions that were asked. The survey was administered during one of my classes by the author herself. 58 of the respondents were male, while 34 were female and the survey was conducted anonymously so the respondents could answer as truthfully as possible without fear of being judged or evaluated.

There were two sections to the questionnaire. The first section consisted of four listening activities, each followed by five questions. The students had to listen to four very short 30 second recordings of female English speakers with different accents. Each speaker in each recording spoke about different subject matters. I deliberately chose accents that I felt were difficult to identify in order to see how well, if at all, students were able to identify the accent, and if any preconceived ideas affected their attitudes towards the accents. Students had to guess what country they thought the speaker came from for the first question. For the next four questions, students had to choose their preference based on a five point Likert scale.

A few of the questions in Section B of the questionnaire were open ended questions so students could express their own opinions.

\section{RESULTS}

\section{Summary For Speaker 1}

After listening to the first speaker in the recording, the students had to identify what country they thought the speaker came from. The actual accent was Malaysian, but the chart below summarizes the answers that most students provided. Students gave a variety of answers, but in order to simplify things, I combined some of the responses. For example, some students wrote Canada, some wrote USA, while others wrote North America. I simply combined all the above answers under the category of North America. Likewise, students also wrote various European countries, which I simply categorized under Europe. 
Table 1: What Country Does Speaker 1 Come From?

\begin{tabular}{|l|c|}
\hline \multicolumn{1}{|c|}{ Country } & Responses \\
\hline North America & 19 \\
\hline England/ UK & 13 \\
\hline Middle East & 13 \\
\hline Europe & 11 \\
\hline Australia & 10 \\
\hline South Africa & 5 \\
\hline Philippines & 5 \\
\hline South America & 4 \\
\hline New Zealand & 3 \\
\hline India & 2 \\
\hline Asia & 2 \\
\hline Vietnam & 1 \\
\hline
\end{tabular}

Only 88 students out of the 92 answered the question shown in Table 1. Even though Malaysia is a South East Asian country, the majority of the responses identified the speaker as having a 'Western' accent. Most surprising was the fact that many students thought the speaker may have come from North America, despite the nonnative accent. I assume that these students probably cannot differentiate various accents, as I myself could not tell the difference between the standard Seoul dialect of Korean to other dialects around the country when I first arrived in Korea. After living here for a number of years, I am still barely able to distinguish the difference between the preferred Seoul dialect and obvious accents from other Korean dialects.

Of those who identified the speaker as North American, 16 of the 19 students could not understand the speaker, 7 students liked the accent while 6 found the accent less appealing, 17 had somewhat positive or neutral opinions of the country/people, yet only 3 students did not want a teacher with this accent. Of these 19 respondents, I also looked over their answers to question 28, where they had to write their reasons for why they preferred teachers from certain countries. About half answered that the North American accent is the standard or original as the main reason. Such results seem to illustrate a certain bias towards an accent perceived to be from an Inner Circle country, even though the reality is otherwise. The overall average rating for question 2, about the opinion of the country or people from the country was 3.05 out of a total of 5 for the 92 respondents. For question 3 , students had a generally low rating for how appealing the accent was with an average rating of 2.63. Most students did not understand the speaker, giving the average rating of 2.22 for question 4. Students seemed evenly split on their preference for an English teacher having Speaker 1's accent, with 34 responding to yes or maybe, and 35 to not really or never.

\section{Summary for Speaker 2}

The second recording was that of a speaker from China. Table 2 illustrates the responses by the students to the identity of the speaker.

Table 2: What country do you think the speaker comes from?

\begin{tabular}{|l|c|}
\hline \multicolumn{1}{|c|}{ Country } & Response Count \\
\hline Asia & 34 \\
\hline Australia & 11 \\
\hline North America & 9 \\
\hline Korea & 6 \\
\hline Middle East & 6 \\
\hline Philippines & 6 \\
\hline South Africa & 5 \\
\hline England/ UK & 5 \\
\hline Europe & 4 \\
\hline India & 1 \\
\hline New Zealand & 1 \\
\hline Not Inner Circle Countries & 1 \\
\hline
\end{tabular}


A majority, 40 of the 92 respondents identified the accent as being Asian or Korean. The average rating for the opinion of the country/people was 3.05, while the majority, 43 students, found the accent not very or unappealing. The average rating for understanding was 2.83 , but 33 students understood the speaker, while only 8 , 18 , and 29 students understood speakers 1,3 , and 4 respectively. 33 students wanted a teacher with this accent, while 39 preferred not to have a teacher with the accent.

What surprised me again was that despite the non-native accent of the speaker, some students still thought the speaker may have come from North America. I took a closer look at these 9 respondents and found that 6 had generally positive ratings for the speaker, but of the 3 that had fairly negative ratings, 2 students gave an enthusiastic 'Yes, please!' to the question "Would you like to have an English teacher with this accent." Most of the 9 students stated that the North American accent was "original" or "standard" or that they" liked the countries" as their main reasons for preference of teachers from these countries.

\section{Summary for Speaker 3}

Table 3 below illustrates the results for question 11 .

Table 3: What country do you think the speaker comes from?

\begin{tabular}{|l|c|}
\hline \multicolumn{1}{|c|}{ Country } & Response Count \\
\hline North America & 55 \\
\hline Europe & 9 \\
\hline Australia & 6 \\
\hline South America & 6 \\
\hline England/ UK & 5 \\
\hline South Africa & 4 \\
\hline South East Asia & 2 \\
\hline Middle East & 2 \\
\hline Hong Kong & 1 \\
\hline
\end{tabular}

The third recording was that of a speaker from South Africa. Quite a majority of students identified the speaker as coming from North America, while only 4 correctly identified the accent. Only 2 students thought the accent sounded Asian. The average rating for positive or negative opinions of the country/people was fairly high at 3.66 and 60 of the 92 respondents found the accent appealing with an average rating of 3.67. Only 18 students understood the speaker for an average rating of 2.77. A large majority, 56 students, liked to have a teacher with this accent for an average rating of 3.65. Of those who correctly identified South Africa, only one student had fairly positive ratings while the other 3 had neutral to negative ratings.

\section{Summary for Speaker 4}

Table 4 below shows the responses to question 16 .

Table 4: What country do you think the speaker comes from?

\begin{tabular}{|l|l|}
\hline \multicolumn{1}{|c|}{ Country } & Response Count \\
\hline Europe & 19 \\
\hline Australia & 14 \\
\hline North America & 13 \\
\hline England/ UK & 9 \\
\hline Asia & 6 \\
\hline Middle East & 5 \\
\hline Philippines & 4 \\
\hline Korea & 4 \\
\hline New Zealand & 4 \\
\hline South Africa & 3 \\
\hline South America & 3 \\
\hline India & 1 \\
\hline Mexico & 1 \\
\hline
\end{tabular}


Speaker 4 had a Swedish accent and although no one was able to correctly identify the country, 19 students did respond with Europe. I believe the variety of answers the students had, showed their unfamiliarity with this particular accent. Nevertheless, the opinions toward the country/people had a fairly high rating at 3.50. 38 students found the accent appealing for another fairly high rating of 3.22. The rating for understanding was 2.98 and the rating for preference of an English teacher with this accent was also pretty high at 3.40.

Of those who thought the speaker came from an Inner Circle country, 23 of the 40 students gave fairly high ratings while only one student gave generally low ratings. Of the 19 students who thought the speaker came from Europe, only 5 gave fairly high ratings while 4 students gave negative ratings.

\section{Summary of Section B}

Most students, 85 out of 92 , felt it was very or somewhat important to learn an accent while 79 out of 92 students thought the accent of the teacher could affect their ability to learn English properly. For question 23, 61\% of the students picked North America as having the most beautiful accent, followed by England at $27 \%$ and Australia at $5 \%$.

For question 24, I encountered a few problems since the question was mistranslated in Korean and therefore confused many of the students. As a result, some of the responses did not make any sense to me and so I disregarded quite a few of the answers. The question asked the students their general opinion of the people from the country they chose as having the most beautiful accent. The Korean translation asked what opinions students had to different accents from different countries. I selected 32 answers and summarized them in Table 5.

Table 5: What is your general opinion of the people from this country?

\begin{tabular}{|l|c|}
\hline \multicolumn{1}{|c|}{ Answers from students } & Response Count \\
\hline Clear/ understandable accent & 13 \\
\hline Natural/ original accent & 6 \\
\hline Pleasant & 5 \\
\hline Comfortable & 4 \\
\hline Developed/ rich/ educated nation & 3 \\
\hline Stylish & 1 \\
\hline
\end{tabular}

As illustrated in table 5, many students seemed to find the accent quite important, although the nature of the survey focusing on accents may have prompted such answers.

Question 25 asked students what accents they found most unpleasant. 57\% of the students chose Asia or South East Asia as having unappealing accents, followed by England or UK at a distant $8 \%$. Japan was the most frequently cited country with $26 \%$ of the votes, followed by the Philippines with $16 \%$. Only 2 people found the USA accent unappealing. The general opinion of the people from the unappealing countries is summarized below in Table 6.

Table 6: What is your general opinion of the people from this country?

\begin{tabular}{|l|l|}
\hline \multicolumn{1}{|c|}{ Answers from students } & Response Count \\
\hline Can't understand & 17 \\
\hline Awkward to listen to & 7 \\
\hline Too harsh sounding & 6 \\
\hline Not original (standard) English & 5 \\
\hline Bad to learn from & 5 \\
\hline Can misunderstand & 4 \\
\hline Doesn't sound like English & 3 \\
\hline Speak too fast & 3 \\
\hline Poor accent can reflect lack of education & 1 \\
\hline Bad intonation & 1 \\
\hline Poor country & 1 \\
\hline
\end{tabular}


One student brought up an interesting point, commenting on how a learner with an accent different from the prestige group, can reflect a lack of education, regardless of how well educated the learner actually is. Such attitudes may hold true in a society like Korea's where even "the social status of a speaker can be deduced from the skill with which they select and use" the different stylistic variations of Korean (Holmes, 2008: 256). Therefore, I feel it may be safe to assume that speaking with the favored accent in such a society may result in perceptions of status and higher level of education regardless of the reality.

\section{Summary of Teacher Preferences}

Table 7 summarizes the results for question 27 regarding teacher preferences.

Table 7: What country or countries do you prefer your English teacher to come from? Please check by preference

\begin{tabular}{|l|c|c|c|c|c|c|c|}
\hline \multicolumn{1}{|c|}{ Country } & Very Much & Somewhat & Neutral & Not very & Not at all & Average & Responses \\
\hline Canada & 39 & 43 & 10 & 0 & 0 & 4.32 & 92 \\
\hline United States & 46 & 38 & 6 & 1 & 1 & 4.38 & 92 \\
\hline Australia & 9 & 51 & 25 & 6 & 1 & 3.66 & 92 \\
\hline New Zealand & 5 & 46 & 35 & 4 & 2 & 3.52 & 92 \\
\hline England & 28 & 32 & 22 & 10 & 0 & 3.85 & 92 \\
\hline Ireland & 2 & 24 & 45 & 17 & 2 & 3.08 & 90 \\
\hline South Africa & 0 & 6 & 35 & 35 & 16 & 2.34 & 92 \\
\hline Philippines & 0 & 7 & 30 & 38 & 17 & 2.29 & 92 \\
\hline Korea & 6 & 23 & 31 & 22 & 0 & 2.92 & 92 \\
\hline Other & 0 & 2 & 49 & 24 & 11 & 2.49 & 86 \\
\hline
\end{tabular}

As shown in Table 7, a large majority of my Korean students prefer English teachers from either Canada or America. Many students also like English teachers from England. Not surprisingly, most students seem to favor the Inner Circle countries. However, I do find it interesting that some students also preferred having Korean teachers teach English. The least preferred countries were South Africa and Philippines, although the listening exercise with speaker 3, a South African accented English speaker had highly favorable ratings with most students, especially when they thought the speaker came from North America. I believe such results reflect problems with how a society can hold a certain group in high esteem, against which other less favored groups are judged (Wardhaugh, 2008).

Table 8 summarizes the students' reasons for why they prefer certain countries.

Table 8: For the country or countries you prefer, please write your reasons for why

\begin{tabular}{|l|c|c|}
\hline \multicolumn{1}{|c|}{ Answers from students } & Response count & Response percent \\
\hline Original/standard pronunciation & 34 & $35 \%$ \\
\hline Familiar/ learned before & 12 & $13 \%$ \\
\hline Clear/ easily understand accent & 11 & $11 \%$ \\
\hline Good teacher from here & 10 & $9 \%$ \\
\hline Rich and powerful country & 9 & $8 \%$ \\
\hline Familiar/ common understanding & 8 & $4 \%$ \\
\hline Friendly country & 4 & $4 \%$ \\
\hline Like & 4 & $1 \%$ \\
\hline Good accent & 1 & $1 \%$ \\
\hline Mysterious (UK) & 1 & $1 \%$ \\
\hline Korean teacher can be helpful & 1 & \\
\hline
\end{tabular}

The most common response with $35 \%$ of the students for their preference, was because they believe the accent from the favored country to be the standard or original model of English. 13\% of the respondents had a preference for certain accents based on their personal experience, being familiar with the pronunciation and having learned from teachers before. One can then assume that perhaps with more exposure to other types of accents from 
various English teachers, students may learn to appreciate various World Englishes, rather than favoring a certain elite group.

Table 9 summarizes the last question in the survey.

Table 9: For the country or countries you least prefer, please write your reasons for why

\begin{tabular}{|l|c|c|}
\hline \multicolumn{1}{|c|}{ Answers from students } & Response Count & Response Percent \\
\hline Difficult to understand & 25 & $25 \%$ \\
\hline Not country of English origin & 18 & $18 \%$ \\
\hline Bad image of the country & 9 & $9 \%$ \\
\hline No reason & 9 & $7 \%$ \\
\hline Unfamiliar/ distant/ can't relate to & 7 & $4 \%$ \\
\hline Not helpful & 4 & $4 \%$ \\
\hline Don't want to acquire the accent & 4 & $4 \%$ \\
\hline Bad accent & 4 & $3 \%$ \\
\hline Not comfortable & 3 & $2 \%$ \\
\hline Second language interference & 2 & $2 \%$ \\
\hline Not pleasant & 2 & $2 \%$ \\
\hline Haven't heard the accent before & 2 & $1 \%$ \\
\hline Too harsh & 1 & $1 \%$ \\
\hline Dislike country & 1 & \\
\hline Korean teachers may miss what Natives can teach & 1 & \\
\hline
\end{tabular}

Many students disliked certain countries because they felt the accent was difficult to understand or because the country was not of English origin. 9\% of students had a negative view of the country itself while 7\% were unfamiliar with or could not relate to the country. For those who felt unfamiliar with the country, I believe can be taught to appreciate the accent in time with more exposure to English teachers from the less favored areas.

\section{PROBLEMS WITH THE STUDY}

First of all, the survey was only administered to 92 of the author's own students. Because the students were mine, this may have affected the results of the survey, and with such a small sample size, the results may not reflect the rest of the university population or even students within our Practical English department. Furthermore, the students were all non-majors of English. I'm curious to see how the results may have changed if English majors were included in the survey. Casual observation and interactions with such students have led me to believe that they may take the survey more enthusiastically due to the importance they generally place in learning English. Another problem was the Korean translation of the questionnaire. As discussed before, a couple of the questions confused students because the translation was not accurate. However, even with accurate translations, students may still have misinterpreted the questions and I may have misinterpreted the responses of the students, all of which of course can affect the results of the survey. Another potential problem may be the students' hesitancy to answer honestly for fear that they were being tested, despite my assurances that the survey was completely anonymous. Being their lecturer may have also added to their potential fear of being judged.

\section{Problems with the recordings}

Another problem and perhaps the most important, involved the recordings. I had originally wanted to record two of my South African colleagues and two South East Asian instructors of English. However, the disparity in the fluency of their spoken English was too great. I resorted to using samples of interviews I found over the internet instead. Although I tried to use speakers with similar English fluency, my own biases may have inadvertently affected my choices. Furthermore, I recorded from the internet so the clarity in sound was not as good as it would have been if I had recorded my colleagues. Despite some of these flaws, I believe the results in this survey do highlight some interesting findings. 


\section{DISCUSSION OF IMPLICATIONS IN KOREA}

The textbook we use at the university where I work does bring in some accented speakers of English in some of its listening exercises. I believe this may be a good start to introducing various accents in the classroom setting aside from the favored North American standard. The university has also made an effort in trying to hire English instructors from various backgrounds. My colleagues now include South African, Irish, New Zealand, Canadian, and American representatives. However, as the results of the survey have shown, students mostly still prefer North American teachers, and the predominant reasons seem to be their familiarity with North American English and their belief that this English is the standard. However, Montgomery (2007) suggests that the sound of the accent has little to do with such beliefs and that social evaluation is what confers positive or negative views on certain patterns of pronunciation. I am inclined to agree with Montgomery as many students held somewhat negative views on South Africa for instance, yet a majority of the same students identified the South African speaker 3 as having a North American accent and accordingly, gave the speaker favorable ratings when they perceived the accent to be North American. On the flip side, most of those who correctly identified speaker 3 as South African, gave poorer ratings. Therefore, the perceived prestige of North America seemed to affect their attitudes more than the actual accents.

On a slightly different note, however, the main reason for disliking a certain country for many students seemed to be their difficulty in understanding the accents. However, the listening exercise at the beginning of the survey revealed that in general, students still preferred speakers 3 and 4, even though more students claimed to understand speaker 2. Regardless of the findings, I do believe that understanding accents in academic listening activities is very important to students. Because Korea places so much importance on various standardized tests, I believe that teachers from Inner Circle countries may and should continue to provide students with the English they are familiar with, in order to help them with their specific academic goals. Society however, should change their focus on Inner Circle English and learn to embrace the idea that various World Englishes have their strengths and uses as well.

\section{CONCLUSION}

This paper summarized the results of a survey given to university students in Korea regarding their attitudes to various accents in English. While the majority of the students surveyed and the current university curriculum favor English from Inner Circle countries, the reality is moving towards other World Englishes as more and more people learn English around the globe. Though negative attitudes may take time to change, I believe in time Englishes from the Outer and Expanding Circles may begin to advance in importance as it follows the ever evolving changing needs of the world.

\section{ACKNOWLEDGEMENT}

This paper was supported by the Hankuk University of Foreign Studies Research Fund 2011

\section{AUTHOR INFORMATION}

Alice Julianna Yoo, as a Canadian-Korean, Alice has lived and worked in Korea for almost 7 years. She has been a professor at the Hankuk University of Foreign Studies in South Korea for over 5 years, and continues to teach the Practical English courses there. E-mail: videlkorea@yahoo.ca.

\section{REFERENCES}

1. Butler, Y.G.. (2007) 'How Are Nonnative-English Speaking Teachers Perceived by Young Learners?' TESOL Quarterly. Vol. 41, No.4: 731-755.

2. Cekic, A. (2009) 'Should We Use American English to Improve Students' Listening Skills?' NovitasROYAL. Vol.3(2): 110-116.

3. Harding, L. 'Accent and Academic Listening Assessment: A Study of Test-Taker Perceptions.' [Accessed Online] www.ltrc.unimelb.edu.au/mplt/papers/13_1_1_Harding.pdf 
4. Holmes, J. (2008) An Introduction to Sociolinguistics. ( $3^{\text {rd }}$ Edition) London: Longman Group UK Limited.

5. Kwon, O. (2000) 'Korea's English Education Policy Changes in the 1990s: Innovations to Gear the Nation for the $21^{\text {st }}$ Century.' English Teaching. Vol. 55, No.1.

6. Montgomery, M. (2007) An Introduction to Language and Society. ( ${ }^{\text {nd }}$ Edition) London: Routledge.

7. Rajadurai, J. (2005) 'Revisiting the Concentric Circles: Conceptual and Sociolinguistic Considerations.' Asian EFL Journal. Vol. 7(4), No. 7.

8. Said, S.B. 'The Perception of Arab-Accented Speech by American Native Speakers and Non-native Speakers from East and South-East Asia.' [Accessed Online] www.personal.psu.edu/sbb170/PAL.pdf.

9. Wardhaugh, R. (2006) An Introduction to Sociolinguistics. (5 ${ }^{\text {th }}$ Edition) Blackwell Publishing.

10. Weeks, S. (1996) 'Embracing English.' In The Miami Herald. [Accessed Online]. 
NOTES 